\title{
Penyuluhan Hukum Tentang Bahaya Penyalahgunaan Narkotika Kepada Pelajar Sekolah Menengah Kejuruan (SMK) Negeri 1 Kabupaten Muaro Jambi
}

\author{
Sahuri Lasmadi, Johni Najwan, M. Zulfa Aulia, Harry Setya Nugraha
}

Fakultas Hukum, Universitas Jambi

\begin{abstract}
Abstrak: Pelajar adalah anak didik adalah amanah sekaligus karunia Tuhan Yang Maha Esa, yang senantiasa harus dijaga karena dalam dirinya melekat harkat, martabat dan hak-hak sebagai manusia yang harus dijunjung tinggi. Diharapkan peran aktif masyarakat khususnya guru di sekolah lebih optimal melalui kegiatan yang diarahkan untuk memiliki pengetahuan dan pemahaman serta kesadaran tentang bahaya penyalahgunaan narkotika. Sekolah Menengah Kejuruan (SMK) Negeri 1 adalah salah satu sekolah menengah yang ada di Kecamatan Sekernan. Kepala Sekolah merupakan mitra pengusul dalam Program Kegiatan Ipteks bagi Masyarakat yang dapat diberdayakan dalam upaya pencegahan penyalahgunaan narkotika terhadap pelajar SMK Negeri 1 Kabupaten Muaro Jambi. Metode yang digunakan adalah pendidikan kepada masyarakat khususnya ditujukan kepada pelajar SMK Negeri 1: (1) Mengadakan Ceramah Sosialisasi UU Norkotika No 35 Tahun 2009; (2) Mengadakan Penyuluhan hukum tentang isi dari Undang-Undang Narkotika No 35 Tahun 2009; (3) Mengadakan diskusi dan tanya jawab tentang materi yang diberikan. Tujuan: (1) Meningkatkan pengetahuan dan pemahaman Mitra melalui penyuluhan hukum, simulasi hukum dimulai dengan sosialisasi UU Narkotika No 35 Tahun 2009: (2) Dapat mencegah penyalahgunaan Narkotika secara dini di kalangan pelajar SMK Negeri 1. Kesimpulan: Pengabdian kepada masyarakat dengan melakukan: Penyuluhan Hukum Tentang Bahaya Penyalahgunaan Narkotika Kepada Pelajar Sekolah Menengah Kejuruan (SMK) Negeri 1 Kabupaten Muaro Jambi”, menunjukkan bahwa akseptabilitas yakni tingkat penyerapan mitra terhadap kegiatan mengalami peningkatan pengetahuan dan pemahaman mitra tentang materi kegiatan. Adanya peningkatan pengetahuan dan pemahaman peserta tentang isi Undang-Undang Nomor 35 Tahun 2009 Tentang Narkotika serta mampu menyampaikan ide atau pemikiran berkaitan dengan Pencegahan secara dini penyalahguna maupun penyalahgunaan narkotika di kalangan pelajar.
\end{abstract}

Kata Kunci: Pelajar, Penyalahgunaan, Narkotika

\section{PENDAHULUAN}

\subsection{Analisis Situasi}

Awal tahun 2015 penegakan hukum di Indonesia menggegerkan dunia Internasional dengan dieksekusinya terpidana mati kasus narkotika, setidaknya awal Desember 2014 Presiden telah menolak 64 pengajuan grasi terpidana narkotika. Selama ini Indonesia memang merupakan sasaran empuk bagi bandar-bandar narkotika internasional dalam peredaran gelap narkotika.

Perkembangan penggunaan narkotika saat ini tidak hanya untuk bidang kesehatan dan ilmu pengetahuan serta teknologi tetapi sudah bergeser kepada tujuan untuk mencari keuntungan yang besar dengan cara menyalahgunakannya. Padahal sanksi pidana yang termuat dalam Undang-Undang Nomor 35 Tahun 2009 Tentang narkotika memuat sanksi pidana yang cukup berat mulai dari pidana denda, penjara, seumur hidup bahkan sampai pidana mati. Pidana mati adalah upaya yang radikal untuk meniadakan orang-orang yang tak dapat diperbaiki lagi, (Andi Hamzah, 1994:27).

Sekali kecanduan mengkonsumsi, sesudah itu mati. Begitulah dampak penggunaan narkotika seperti heroin atau yang kadarnya yang lebih rendah seperti putaw. Seorang aktivis yang kenal lelah merehabilitasi narkotika Joyce Siti Hanna Djaelani Gordon, menyatakan: "Memang pertama menggunakan putaw rasanya tidak enak. Bahkan, ada yang mengaku mual dan muntah-muntah. Namun, setelah yang kedua dan seterusnya akan ketagihan dan kadarnya terus bertambah" (Forum Keadilan No 46, 2012: 11). 
Menurut Joyce, $80 \%$ dari pasien yang keluar dari tempat rehabilitasi narkotika, umumnya kembali ke tempat rehabilitasi. Penyebabnya, mantan pasien rehabilitasi tersebut kembali mengkonsumsi narkotika. Pecandu menurutnya secara medis tidak bisa diobati, karena narkotika itu telah merusak bagian vital seperti otak, jantung dan paru-paru dan lambung. Jika pecandu putaw diotopsi maka ginjal dan paru-parunya akan kelihatan bolongbolong.

Prinsip kerjanya, narkotika jenis heroin/putaw melemahkan kerja jantung. Denyut jantung akan melemah membuat sipemakai merasa rileks. Berbeda dengan cara kerja shabu atau ekstasi yang memiliki komponen amphetamin dan methapethamin yang mendorong kerja jantung secara berlebihan. Penggunaan kedua jenis narkotika dipastikan bisa merusak secara psikis dan fisik. Khusus ekstasi dan shabu yang memiliki kandungan halusinogenik yang berperan membuat si pemakai berhalusinasi terhadap objek-objek yang dilihatnya juga pananoid. Pengguna narkotika ekstasi dan shabu yang belebihan kerap kali berujung pada kematian, karena over dosis.

Meski tidak bisa disembuhkan secara total, pecandu narkotika itu masih dapat diselamatkan asalkan motivasinya kuat, baik dari diri sendiri maupun lingkungan. Lama pengobatan biasanya antara 8 hingga 12 bulan menurut dr. Djody, " tergantung motivasi yang bersangkutan untuk sembuh. Jika motivasinya kuat, bisa lebih cepat".

Data BNN tahun 2008, terdapat 1,99\% atau 3,6 juta populasi penduduk Indonesia itu menjadi korban dan pecandu narkotika. Data BNN dari tahun ke tahun pengguna narkotika terus meningkat. Tahun 2010 diperkirakan jumlah penyalahgunaan mencapai 4,02 juta jiwa dan pada tahun 2011 sudah mencapai 5 juta jiwa. Perkiraan BNN itu bisa lebih, mengingat banyak korban yang tidak bersedia melapor. Aparat Kepolisian yang seharusnya memberantas peredaran narkotika tidak sedikit yang terjerat. Pecandu juga dapat menyebabkan kematian bagi orang lain. Contohnya Afriyanti Susanti, pengemudi "Xenia maut" yang pada tanggal 22 Januari 2012 menabrak dan menewaskan sembilan orang pejalan kaki.

Pecandu sudah tentu amat menyusahkan keluarga. Seorang ibu berusia 30 tahun, sebut saja Susan dengan anak semata wayangnya pada tahun 2008 memilih kabur dari rumah. Ia tak tahan lagi menghadapi perilaku suaminya yang kecanduan narkotika. Suami Susan sebut saja Robert sudah berulang kali berjanji untuk bertobat. Tapi jangankan menjauhi narkotika, pria berusia 35 tahun itu malah makin menjadi-jadi. Karena pengaruh narkotika perilakunya tidak terkontrol. Ia jadi ringan tangan dan suka mengeluarkan kata-kata kotor.

Pernah suatu kali, ketika sakaw Robert datang ke kantor Susan. Sang isteri yang menjabat sebagai manager keuangan di perusahaan ternama dimaki-maki di depan rekan kerjanya. Tentu saja, Susan malu bukan main. "Saat itu saya benar-benar malu. Dikantor saya dihormati oleh suami malah dimaki-maki. Saya merasa tidak mempunyai harga diri lagi di hadapan anak buah saya" ujarnya di sebuah media masa.

Susan sendiri mengaku sudah melakukan banyak hal untuk menyadarkan suaminya. Dari sekadar nasehat sampai mengirimnya ke panti rehabilitasi. "Puluhan juta habis untuk biaya rehabilitasi. Hasilnya nol,"kata Susan dengan penuh emosi. Akhirnya, dia tak tahan lagi. Ia memilih angkat kaki dari rumah dan kembali ke rumah orang tua. Tak lama setelah kembali ke pangkuan orang tua. Susan mendengar khabar Robert meninggal dunia di rumah sakit akibat over dosis. Robert tentu bukan satu-satunya pria yang tak kuasa melepaskan diri dari 
jerat narkotika. Setiap hari sedikitnya 40-50 nyawa melayang akibat penyalahgunaan narkotika. Setiap tahun 3000 an rakyat Indonesia yang menjemput ajal karena narkotika. Penyalahgunaan narkotika seluruh Indonesia tercatat 4,5 juta juta orang. Dari jumlah itu 1,2 jutA tidak bisa direhabilitasi karena sudah sangat parah. Itupun diyakini hanya fenomena gunung es (Forum keadilan No 34. Januari 2015: 14).

Pecandu hanya ditempatkan sebagai korban dan berhak untuk direhabilitasi dan diobati. Padahal proses pengobatan membutuhkan waktu lama, biaya besar besar dan tentu merepotkan. Terhadap pecandu berat tersebut, hukum yang berlaku di Indonesia, UndangUndang Nomor 23 Tahun 2009 tentang Narkotika. Pengguna narkotika bukan kriminal tapi sebagai korban yang harus direhabilitasi. Pasal 54 Undang-Undang Narkotika.

Apa yang kita saksikan dewasa ini adalah ancaman terhadap kerusakan kehidupan generasi muda yang perlahan tapi pasti, karena penyalahgunaan narkotika. Permasalahan penyalahgunaan narkotika merupakan ancaman besar bagi bangsa Indonesia khususnya generasi muda yang menyebabkan kematian jutaan jiwa. Penyebab remaja terlibat dalam penggunaan narkotika berasal dari remaja sendiri terdorong oleh rasa ingin tau, ingin mencoba, mencari identitas serta gampang menerima tawaran teman sebaya karena ingin diakui atau diterima oleh kelompok sebaya untuk menyalahgunakan narkotika.

Kondisi di lapangan sangat memiriskan karena Provinsi Jambi dalam penyalahgunaan narkotika menempati peringkat 6 (enam) di tingkat nasional, sedangkan untuk peredaran gelap narkotika menempati rangking XIV dari 33 Provinsi. Penyalahguna narkotika di Jambi sebanyak 50.420 (data tahun 2010), HIV/AIDS berjumlah 786 (data bulan Desember 2012), yang masuk penjara 1047 orang (data Januari 2013) yang sakit jiwa rata rata 70 s.d 100 orang tiap tahun. (Sumber, BNNP Jambi, 18 Maret 2013). Terlebih lagi jenis ganja terbaik ke 2 di dunia berada di Provinsi Jambi, yaitu di Kabupaten Kerinci.

Anak didik bukan hanya objek tetapi juga sebagai subjek dalam pencegahan dan penanggulangan penyalahgunaan narkotika. Penyalahgunaan narkoba juga merupakan masalah perilaku manusia. Perubahan perilaku dengan peningkatan keterampilan diri dan percaya diri, sangat diperlukan oleh anak didik untuk mengatasi penyalahgunaan narkotika melaui proses pendidikan.Kegiatan pengabdian masyarakat ini dianggap sangat relevan untuk mendukung program pemerintah dalam rangka pemahaman UU Narkotika, karena dengan kegiatan ini banyak dilakukan sharing dan diskusi dengan para ahli dan mitra sasaran untuk lebih memahami muatan dan isi UU Narkotika, serta menentukan kebijakan serta langkahlangkah strategis dalam usaha pencegahan dan penanggulangan narkotika di Kabupaten Muaro Jambi.

Mengingat betapa bahayanya narkotika bagi tubuh manusia, jika pemakaiannya disalahgunakan. Oleh sebab itu bagi anak didik yang belum paham akibat yang ditimbulkan dari pemakaian narkotika secara tidak benar. Kami tim pengabdian merasa penting untuk melakukan penyuluhan hukum tentang penanggulangan narkotika terhadap pelajar di Sekolah Menengah Kejuruan (SMK) Negeri 1 Kabupaten Muaro Jambi.

\subsection{Permasalahan Mitra}


Persoalan narkotika merupakan permasalahan yang kompleks yang melibatkan pengedar, pemakai/pengguna, pemilik yang masing-masing mempunyai kualifikasi tersendiri. Dalam kesempatan ini permasalahan yang akan menjadi perhatian adalah pecandu atau pemakai narkotika, yaitu: "Masih banyaknya perilaku menyimpang dalam kaitannya dengan narkotika, oleh sebab itu pemahaman terhadap bahaya narkotika bagi pengguna, pecandu merupakan hal yang sangat penting untuk dilakukan penyuluhan hukum". Permasalahan dapat diidentifikasi sebagai berikut:

1. Mitra belum mengetahui Undang-Undang Nomor 35 T ahun 2009 Tentang Narkotika.

2. Mitra belum memahami isi dari Undang-Undang Nomor 35 Tahun 2009 Tentang Narkotika.

3. Belum adanya Program Sekolah dalam upaya pencegahan secara dini penyalahgunaan narkotika di kalangan pelajar.

\subsection{Tujuan Pengabdian Pada Masyarakat}

Kegiatan pengabdian pada masyarakat ini dilakukan dengan tujuan sebagai berikut:

\section{Tujuan Umum}

Mensosialisasikan peraturan tentang narkotika kepada pelajar SMK Negeri 1 Kabupaten Muaro Jambi, sehingga lebih berhati-hati terhadap masalah-masalah penyimpangan perilaku yang kemungkinan besar dapat menimpa seseorang, terlebih adalah anak-anak.

2. Tujuan Khusus

a. Memberikan gambaran pemahaman kepada masyarakat (Pelajar SMK Negeri 1) tentang bahaya narkotika, apalagi jika sudah menjadi pecandu, pemakai atau pengguna bagi kesehatan yang bersangkutan.

b. Dapat mencegah penyahgunaan narkotika terhadap anak secara Dini.

c. Pelajar (Anak Didik) dapat menjadi Motivator sebagai Agen pencegahan narkotika sejak dini di kalangan pelajar sebayanya.

\subsection{Manfaat Pengabdian Pada Masyarakat}

Dari kegiatan pengabdian pada masyarakat ini diharapkan pelajar (anak didik) mendapatkan pemahaman akan bahaya akibat penyalahgunaan narkotika bagi pengguna, pecandu maupun pemakai. Setelah mengetahui bahaya narkotika diharapkan masyarakat pelajar (anak didik) tidak terjebak dalam lingkaran narkotika.

\section{TARGET DAN LUARAN}

\subsection{Target}

Kegiatan pengabdian pada masyarakat "Penyuluhan Hukum Tentang Bahaya Penyalahgunaan Narkotika Kepada Pelajar Sekolah Menengah Kejuruan (SMK) Negeri 1 Kabupaten Muaro Jambi". Berkaitan dengan narkotika, siapapun dapat berpotensi untuk menjadi "Penyalahguna" maupun "Penyalagunaan" narkotika. Oleh karena itu target dan sasaran penyuluhan hukum ini ditujukan kepada terutama: Pelajar Sekolah Menengah Kejuruan (SMK) Negeri 1 Kabupaten Muaro Jambi. Penyebab pelajar (anak didik) terlibat dalam penggunaan narkotika berasal dari anak itu sendiri terdorong oleh rasa ingin tau, ingin mencoba, mencari identitas serta gampang menerima tawaran teman sebaya karena ingin diakui atau diterima oleh kelompok. Melalui Penyuluhan Hukum Tentang Bahaya Penyalahgunaan Narkotika Kepada Pelajar Sekolah Menengah Kejuruan (SMK) Negeri 1 
Kabupaten Muaro Jambi”. Diharapkan dapat memberikan pencerahan kepada masyarakat khususnya para pelajar (anak didik) untuk mengatakan tidak pada narkotika dan dapat menjadi agen pencegahan narkotika di Sekolah Menengah Kejuruan (SMK) Negeri 1 Kabupaten Muaro Jambi.

\subsection{Luaran}

1. Mitra mampu menyerap pengetahuan dan mampu memahami isi Undang-Undang Nomor 35 Tahun 2009 Tentang Narkotika;

2. Publikasi Ilmiah di jurnal, tahun ke 1 Target: Accepted

3. Peningkatan Pemahaman dan Keterampilan masyarakat, tahun ke 1 Target: ada;

4. Laporan pelaksanaan kegiatan dan jurnal pengabdian pada masyarakat.

\section{METODE PELAKSANAAN}

Adapun metode yang dilakukan dalam kegiatan pengabdian masyarakat ini adalah dalam bentuk penyuluhan hukum yang dilakukan dengan beberapa tahapan.

\section{Persiapan,}

Merupakan kegiatan awal yang dilakukan dengan cara Audiensi kepada Sekolah Menengah Kejuruan (SMK) Negeri 1 Kabupaten Muaro Jambi, untuk menyapaikan surat permohonan serta izin guna mengadakan penyuluhan pada sekolah dimaksud. Persiapan untuk menentukan lokasi kegiatan, jumlah peserta, hari dan tanggal kegiatan. Tahap berikutnya menyebarkan undangan dan konfirmasi kehadiran peserta dalam kegiatan pengabdian pada masyarakat.

\section{Materi kegiatan,}

Dalam hal ini penyampaian materi tentang perlindungan terhadap Bahaya Narkotika oleh NARASUMBER. Kegiatan ini dihadiri oleh kurang lebih 50 orang pelajar siswa SMK Negeri 1 Kabupaten Muaro Jambi dengan materi sebagaimana diatur dalam UndangUndang Nomor 35 Tahun 2009 Tentang Narkotika, sebagai berikut: Mengadakan Penyuluhan hukum tentang isi hukum dari Undang-Undang Narkotika No 35 Tahun 2009.

- Kebijakan Pemerintah Tentang Tindak Pidana Narkotika;

- Perbuatan-perbuatan yang termasuk Tindak Pidana Narkotika;

- Perluasan Teknik Penyidikan dalam Tindak Pidana Narkotika;

- Perlindungan Bagi Korban Tindak Pidana Narkotika, Berkaitan dengan Masalah Rehabilitasi bagi Pengguna dan Pencandu Narkotika;

- Pemidanaan (Sanksi) Terhadap Pelaku Tindak Pidana Narkotika.

\section{Kegiatan Pokok,}

- Peran BNN Provinsi Jambi dalam Upaya Pencegahan Narkotika.

1. Mengadakan Ceramah Sosialisasi UU Norkotika No 35 Tahun 2009, yaitu mensosialisasikan Undang-Undang No 35 Tahun 2009. Bahwa narkotika di satu sisi adalah obat atau bahan yang bermanfaat di bidang pengobatan atau pelayanan kesehatan dan pengembangan ilmu pengetahuan disisi lain dapat menimbulkan ketergantungan yang sangat merungikan apabila disalahgunakan atau digunakan tanpa pengendalian dan pengawasan yang ketat dan seksama. Ada terdiri atas 3 golongan, yaitu golongan 1, 2 dan 3 serta golongan dan jenis precursor.

2. Penyampaian materi dengan metode ceramah dengan materi tentang Norkotika, jenisjenisnya, perbuatan-perbuatan yang melawan hukum berkaitan dengan narkotika, serta sanksi pidana berkaitan dengan narkotika. 
3. Penyampaian materi dengan memberikan contoh-contoh kasus berkaitan dengan narkotika serta akibat negatif dari pemakai, pengguna bagi kesehatan.

4. Mengadakan Penyuluhan hukum tentang isi hukum dari Undang-Undang Narkotika No 35 Tahun 2009.

- Kebijakan Pemerintah Tentang Tindak Pidana Narkotika;

- Perbuatan-perbuatan yang termasuk Tindak Pidana Narkotika;

- Perluasan Teknik Penyidikan dalam Tindak Pidana Narkotika;

- Perlindungan Bagi Korban Tindak Pidana Narkotika, Berkaitan dengan Masalah Rehabilitasi bagi Pengguna dan Pencandu Narkotika;

- Pemidanaan (Sanksi) Terhadap Pelaku Tindak Pidana Narkotika.

- Program- Program Peran Serta Masyarakat dengan Pihak BNN.

5. Mengadakan diskusi dan tanya jawab tentang materi yang diberikan.

6. Mengadakan simulasi hukum dalam bentuk Kuis dan latihan menyelesaikan masalah hukum tentang narkotika.

\section{Evaluasi}

Evaluasi Kegiatan akan dilakukan berdasarkan hasil diskusi dan tanya jawab dengan khalayak sasaran, untuk perbaikan ke depan.

\section{Penyusunan Laporan}

Penyusunan laporan merupakan salah bentuk pertanggungjawaban tim atas kegiatan pengabdian masyarakat yang telah dilakukan.

\section{BAB IV. KELAYAKAN UNIVERSITAS JAMBI}

Perguruan Tinggi dalam hal ini diwakili oleh Lembaga Pengabdian Masyarakat (LPM) bertindak sebagai penanggung jawab seluruh kegiatan pengabdian yang dilakukan oleh Dosen di lingkungan Universitas Jambi dalam pelaksanaan TRI DHARMA Perguruan Tinggi. Alokasi dana yang tersedia sangat menunjang kegiatan pengabdian dan ketersediaan tenaga ahli di bidangnya masing-masing.

Universirtas Jambi selaku lembaga pendidikan yang mengemban tugas pelaksana Tri DHARMA PERGURUAN TINGGI bertanggung jawab atas atas pelaksanaan program tersebut, baik penyiapan tenaga ahli maupun fasilitas, sarana prasarana serta alokasi dana yang tersedia sangat menunjang kegiatan pengabdian dan ketersediaan tenaga ahli di bidangnya masing-masing.

Lembaga Pengabdian Pada Masyarakat (LPM), merupakan salah satu perangkat lembaga struktural yang ada di Universitas Jambi, secara teknik operasional merupakan Lembaga yang bertanggung jawab dalam pelaksanaan kegiatan pengabdian pada masyarakat.

Kami salah Tim pengusul dari unsur akademisi Fakultas Hukum Universitas Jambi, akan melakukan kegiatan pengabdian pada masyarakat dengan judul; "Penyuluhan Hukum Tentang Bahaya Penyalahgunaan Narkotika Kepada Pelajar Sekolah Menengah Kejuruan (SMK) Negeri 1 Kabupaten Muaro Jambi”.

\section{HASIL DAN PEMBAHASAN}

\subsection{Pelaksanaan Penyuluhan}

a. Lokasi Penyuluhan

Lokasi kegiatan penyuluhan hukum ini dilaksanakan di Aula Sekolah Menengah Kejuruan (SMK) Negeri 1 Kabupaten Muaro Jambi.

b. Materi dan Jadwal Penyuluhan

\begin{tabular}{|l|l|l|l|l|}
\hline No & Hari/Tgl & Kegiatan & Narasumber & Ket \\
\hline
\end{tabular}




\begin{tabular}{|c|c|c|c|c|c|}
\hline 1 & $\begin{array}{l}\text { Jumat, } \\
06 \text { Sep } \\
2017\end{array}$ & \multicolumn{3}{|c|}{ Evaluasi sebelum kegiatan penyuluhan } & \multirow[t]{2}{*}{$\begin{array}{l}\text { Tim Penyuluhan dan } \\
\text { Instruktur }\end{array}$} \\
\hline 2 & $\begin{array}{l}\text { Jumat, } \\
06 \text { Sep } \\
2017\end{array}$ & \multicolumn{3}{|c|}{ 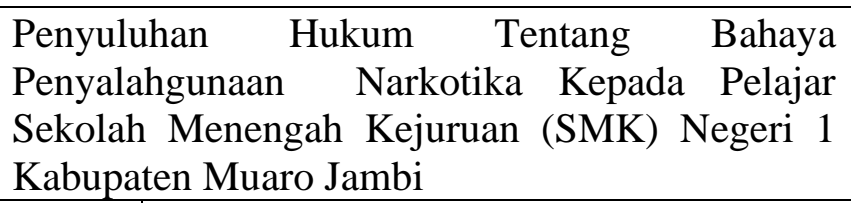 } & \\
\hline \multicolumn{3}{|c|}{ Jam } & \multicolumn{2}{|c|}{ Materi } & \\
\hline \multicolumn{3}{|c|}{08.30 wib - 09.30 wib } & \multicolumn{2}{|c|}{$\begin{array}{l}\text { Perbuatan-perbuatan yang termasuk } \\
\text { tindak pidana narkotika }\end{array}$} & \multirow{6}{*}{$\begin{array}{l}\text { Tim Penyuluhan dan } \\
\text { Instruktur }\end{array}$} \\
\hline \multicolumn{3}{|c|}{09.30 wib - 11.30 wib } & \multicolumn{2}{|c|}{ Penanggulangan Narkotika } & \\
\hline \multicolumn{3}{|c|}{$11.00 \mathrm{wib}-12.00 \mathrm{wib}$} & \multicolumn{2}{|c|}{ Peran BNN } & \\
\hline \multicolumn{3}{|c|}{12.00 wib - 14.00 wib } & \multicolumn{2}{|c|}{ Isoma } & \\
\hline \multicolumn{3}{|c|}{$14.00 \mathrm{wib}-15.30 \mathrm{wib}$} & \multicolumn{2}{|c|}{ Rehabilitasi } & \\
\hline \multicolumn{3}{|c|}{$15.30 \mathrm{wib}-17.00 \mathrm{wib}$} & \multicolumn{2}{|c|}{$\begin{array}{l}\text { Pemidanaan terhadap pelaku tindak } \\
\text { pidana narkotika }\end{array}$} & \\
\hline \multicolumn{2}{|c|}{\begin{tabular}{l|l} 
& Sabtu, \\
$7-9-$ \\
2018
\end{tabular}} & \multicolumn{2}{|c|}{$\begin{array}{l}08.00-09.00 \mathrm{wib} \\
10.00-11.00 \mathrm{wib}\end{array}$} & Diskusi dan Evaluasi & $\begin{array}{l}\text { Tim Penyuluhan dan } \\
\text { Instruktur }\end{array}$ \\
\hline
\end{tabular}

\section{c. Hasil Monitoring dan Evaluasi}

Kegiatan monitoring dan evaluasi dilakukan secara bersamaan selama kegiatan penyuluhan berlangsung. Instrumen yang digunakan meliputi pengamatan secara langsung mengenai sikap dan melalui daftar pertanyaan atau kuis yang diberikan langsung oleh Tim Penyuluhan. Hasil kegiatan monitoring dan evaluasi dapat dilihat pada tabel berikut ini:

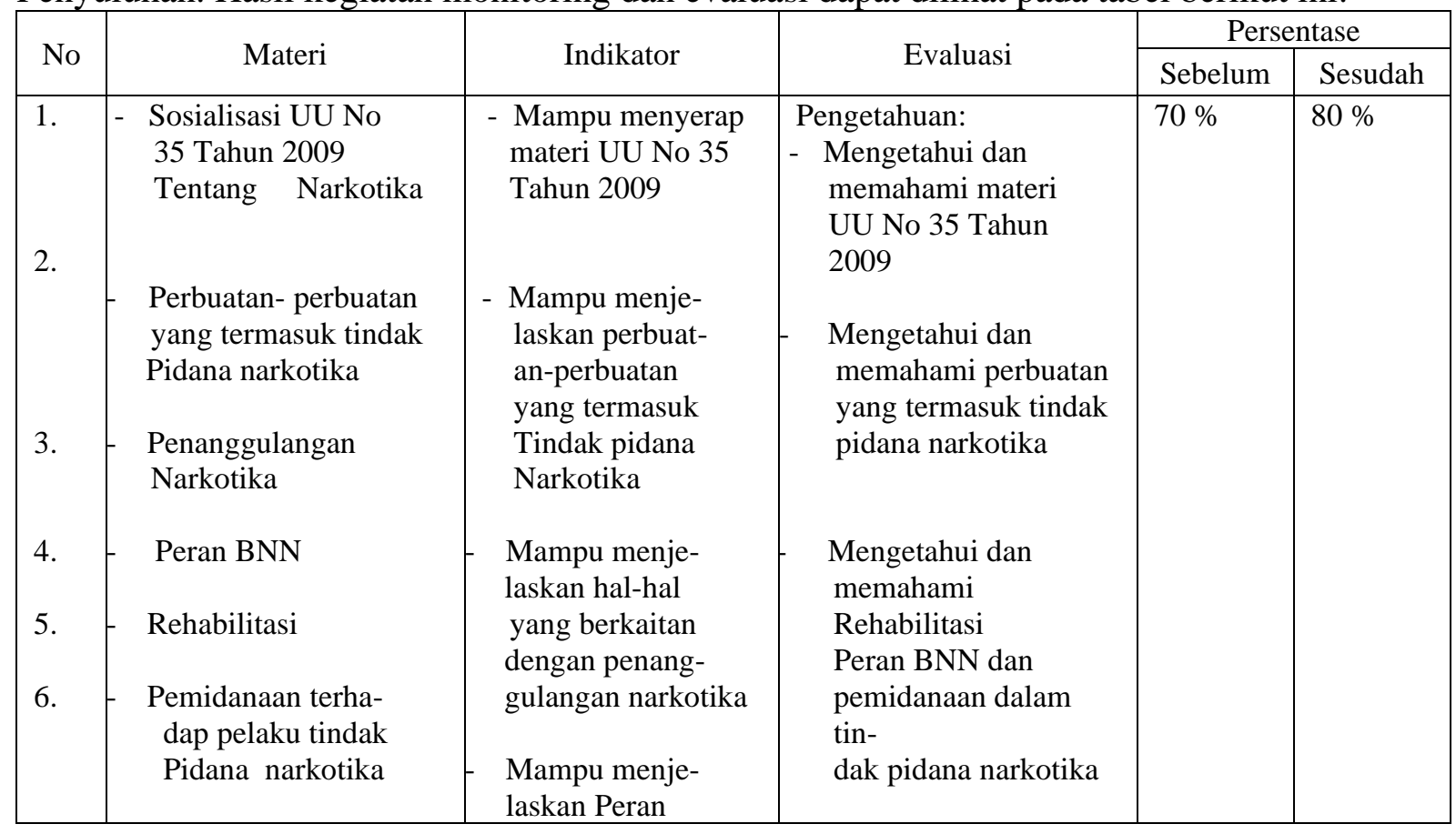




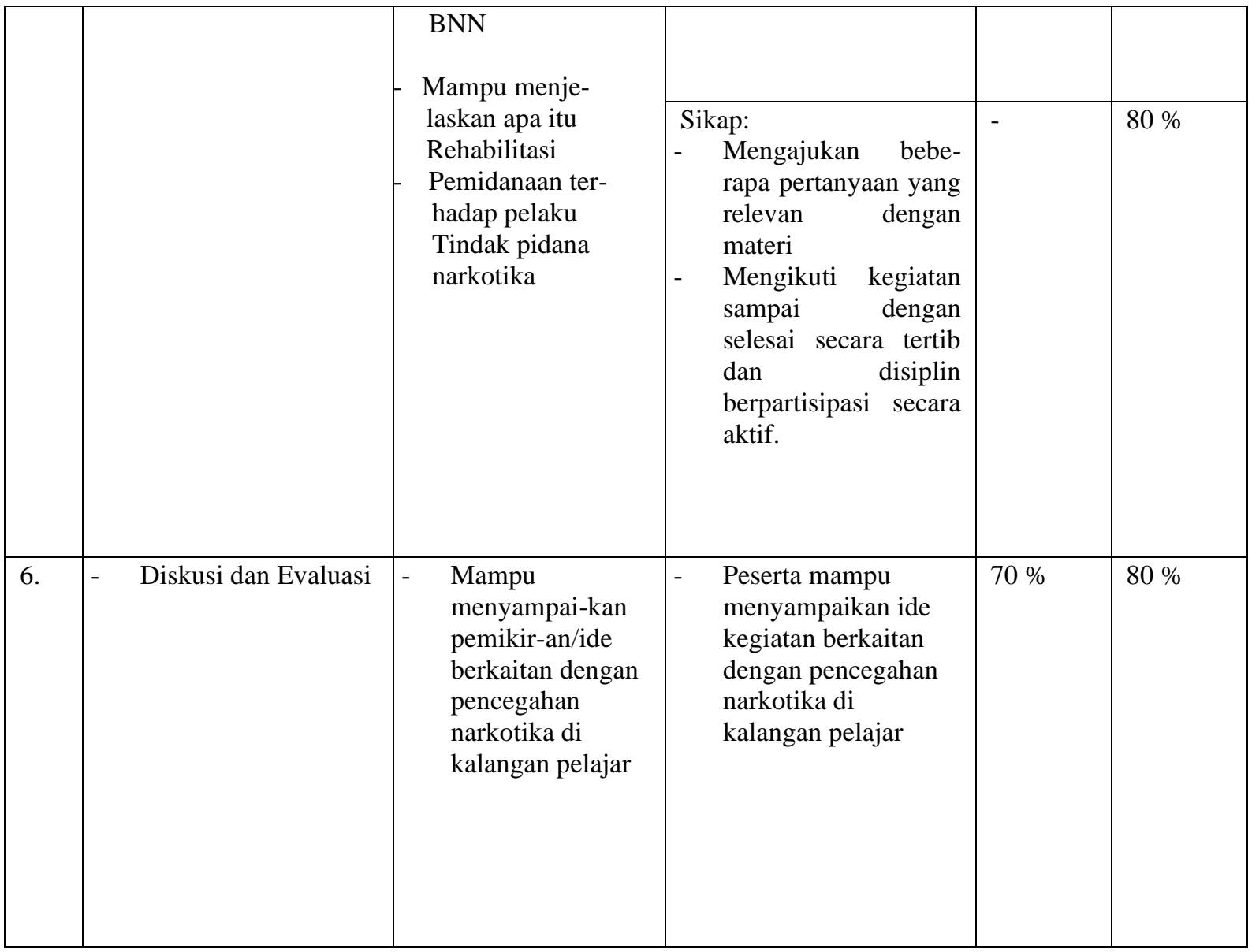

Berdasarkan hasil evaluasi yang dilakukan melalui kuis sebelum maupun setelah kegiatan dilaksanakan serta pengamatan selama kegiatan penyuluhan maka diperoleh hasil sebagai berikut:

1. $80 \%$ peserta penyuluhan mengetahui dan memahami materi tentang narkotika dan mampu menjelaskan isi dari materi berkaitan dengan pencegahan narkotika di kalangan pelajar.

2. $80 \%$ peserta penyuluhan berpartisipasi secara aktif selama kegiatan berlangsung dengan ditandai pertanyaan-pertanyaan yang diajukan sesuai dengan materi penyuluhan serta menunjukkan kedisiplinan dan tata tertib selama mengikuti kegiatan.

3. $80 \%$ peserta penyuluhan mampu menyampaikan ide pemikiran berkaitan dengan pencegahan narkotika di kalangan pelajar.

Selama kegiatan penyuluhan, peserta menunjukkan sikap antusias dengan ditandai banyaknya pertanyaan yang diajukan oleh para peserta kepada narasumber/instruktur. Beberapa pertanyaan yang diajukan oleh peserta penyuluhan antara lain sebagai berikut:

1. Putri Puspita Dewi

Pertanyaan: Bagaimana rehabilitasi bagi pengguna narkotika?

Jawab:

Pada Pasal 54 dinyatakan bahwa: Pecandu narkotika dan korban penyalahgunaan Narkotika wajib menjalani rehabilitasi medis dan rehabilitasi sosial. Selanjutnya pada Pasal 55 dinyatakan bahwa:

(1)Orang tua atau wali dari Pecandu Narkotika yang belum cukup umur wajib melaporkan kepada pusat kesehatan masyarakat, rumah sakit, dan/atau lembaga 
rehabilitasi medis dan rehabilitasi sosial yang ditunjuk oleh pemerintah untuk mendapatkan pengobatan dan/atau perawatan melalui rehabilitasi medis dan rehabilitasi sosial;

(2)Pecandu Narkotika yang sudah cukup umur wajib melaporkan diri atau dilaporkan oleh keluarganya kepada pusat kesehatan masyarakat, rumah sakit, dan/atau lembaga rahabilitasi medis dan rehabilitasi sosial yang ditunjuk oleh Pemerintah untuk mendapatkan pengobatan dan/atau perawatan melalui rehabilitasi medis dan rehabilitasi sosial;

Jika pengguna narkotika dijatuhkan pidana dan disebutkan dalam putusan hakim disertai rehabilitasi medis dan rehabilitasi sosial, maka masa pidana dijalani berbarengan dengan rehabilitasi medis dan rehabilitasi sosial.

2. Riski Pratama

Pertanyaan: Bagaimana mengetahui orang di sekitar kita menggunakan

Narkotika?

Jawab:

Tanda-tanda dini pengguna narkotika:

1. Menurunnya nilai rapot;

2. Suka menyendiri, cari alasan agar dapat keluar kelas atau rumah;

3. Kamar anak selalu tertutup dan kamar yang dulu rapi sekarang berantakan;

4. Berpakaian tidak rapi;

5. Terdapat bau aneh yang tidak biasa di kamar;

6. Anak berwajah pucat, mata dan hidung berair, tangan gemetar, gelisah;

7. Barang anak, barang milik orang tua di rumah mulai hilang;

8. Suka memakai baju lengan panjang,;

9. Mudah tersinggung dan napas tersengal- sengal.

3. Paulina Arta Kirana

Pertanyaan: Apakah pengguna narkotika berpengaruh kepada keturunan, jika pengguna itu adalah seorang suami ?

Jawab:

Perlu dilakukan cek darah, air kencing, rambut. Jika pengguna narkotika sudah terinfeksi HIV/AID, jika pengguna adalah seorang suami dikhawatirkan akan menularkan penyakit tersebut kepada istri keturunannya, karena penularan dapat terjadi melalui hubungan seksual dan melalui jarum suntik.

4. Mawaddah Hawani

Pertanyaan: Bagaimana cara kita menyikapi sekarang ini banyak makanan yang mengandung narkotika?

Jawab:

Jika kita berbelanja yang perlu diperhatikan oleh konsumen adalah komposisi Yang terkandung pada kemasan makanan, terdaftar di BPOM, lihat tanggal kadaluarsanya.

5. Ika Rayani

Pertanyaan: Apa yang harus kita lakukan jika di sekitar tempat tinggal kita

Jawab: ada pelaku yang menggunakan narkotika?

Sebagai bentuk partisipasi masyarakat dan sebagai warga negara yang baik kita wajib melaporkan pelaku, jika pelaku adalah pengguna maka dia akan menjalani rehabilitasi medis maupun rehabilitasi sosial, sebaliknya jika pelaku adalah pengedar maka akan diproses sesuai hukum yang berlaku. 


\section{KESIMPULAN DAN SARAN \\ 6.1. Kesimpulan}

Pengabdian kepada masyarakat dengan melakukan: Penyuluhan Hukum Tentang Bahaya Penyalahgunaan Narkotika Kepada Pelajar Sekolah Menengah Kejuruan (SMK) Negeri 1 Kabupaten Muaro Jambi", menunjukkan bahwa akseptabilitas yakni tingkat penyerapan mitra terhadap kegiatan mengalami peningkatan pengetahuan dan pemahaman mitra tentang materi kegiatan.

\subsection{Saran}

Kegiatan penyuluhan hukum tentang narkotika ini sangat bermanfaat terhadap pelajar maupun mahasiswa sebagai upaya pencegahan dini atas penyalahguna maupun penyalahgunaan narkoba di kalangan pelajar dan mahasiswa. Oleh sebab itu kegiatan ini dapat dilakukan secara berkelanjutan dengan lokasi yang berbeda.

\section{DAFTAR PUSTAKA}

Andi Hamzah, dkk. 1994. Pidana Mati di Indonesia di Masa Lalu, Kini, dan Masa Depan. Ghalia Indonesia, Jakarta.

Gatot Supramono. 2004. Hukum Narkoba Indonesia. Djambatan, Jakarta.

Hari Sasangka. 2003. Narkotika dan Psikotropika Dalam Hukum Pidana. Mandar Maju, Bandung.

Mardani. 2008. Penyalahgunaan Narkoba Dalam Perspektif Hukum Islam dan Hukum Pidana Nasional. Raja Grafindo Persada, Jakarta.

Moh. Taufik Makaro, dkk. 2005. Tindak Pidana Narkotika. Ghalia Indonesia, Jakarta

Romli Atmasasmita. 1997. Tindak Pidana Narkotika Transnasional Dalam sistem Hukum Pidana Indonesia. Citra Adtya Bakti. Bandung.

Siswanto, H. 2012. Politik Hukum Dalam Undang-Undang Narkotika, PT. Rineka Cipta, Jakarta.

Undang-Undang Republik Indonesia Nomor 35 Tahun 2009 Tentang Narkotika.

Forum Keadilan Edisi No 34 Januari 2015 